\title{
Inhibitory effects of different medicinal plants on the growth of some oral microbiome members
}

\author{
ZORAN TAMBUR, BILJANA MILJKOVIĆ-SELIMOVIĆ*, DOLORES OPAČIĆ**, \\ EMA ALEKSIĆ, LUKA IVANČAJIĆ ${ }^{* * *}$, BOJAN JOVIČIĆ**, BRANISLAVA VUKOVIĆ
}

Faculty of Stomatology, Pancevo, Serbia,

*Faculty of Medicine, University of Nis, Nis, Serbia

**Military Medical Academy, Belgrade, Serbia

${ }^{* * *}$ City Institute of Public Health, Belgrade, Serbia

Tambur Z., Miljković-Selimović B., Opačić D., Aleksić E., Ivančajić L., Jovičić B., Vuković B. Inhibitory effects of different medicinal plants on the growth of some oral microbiome members

Summary

Oral infections and dental caries are still considered as a serious public health problem. Using the method of minimum inhibitory concentrations (MICs), the aim of this study was to investigate the inhibitory effects of 16 plants on the growth of Actinomyces odontolyticus, Streptococcus mitis, Streptococcus sanguinis, Eikenella corrodens, Fusobacterium nucleatum, Lactobacillus acidophilus and Streptococcus mutans. The most effective were ethanol extracts of Rosmarinus officinalis, Salvia officinalis, Thymus vulgaris, Calendula officinalis and Hypericum perforatum. The least efficiency was observed for Acorus calamus extract. Plant extracts could be used in oral health as therapeutic and prophylactic approach or in balancing oral microbiota.

Keywords: medicinal plants, oral cavity bacteria, antimicrobial activity

The human oral microbiota consists of 500 to 700 common oral species of bacteria $(19,9)$. Nearly 300 bacterial species have been isolated and named belonging to several phyla, including Bacteroidetes, Firmicutes, Tenericutes, Actinobacteria, Proteobacteria, Euryarchaeota, Chlamydiae, and Spirochaetes (26). Molecular methods using 16S rRNA studies identified approximately 600 species or phylotypes (24). When oral microbiota is balanced its presence in the oral cavity is protective against local and systemic diseases. Since oral microbiota is influenced by many factors, such as underlying diseases, food, $\mathrm{pH}$, aging etc., they can lead to normal microbiota being replaced by etiological agents of pathological processes (15). Some of the members of oral cavity microbiota, such as Streptococcus mutans and Lactobacillus spp., play a role in the etiology of caries, others are important in the etiology of gingivitis and various paradontopathies, and even in various types of oral pyogenic processes, such as abscess and osteomyelitis (9). In addition, oral cavity microorganisms have been shown to cause a number of systemic diseases, including cardiovascular diseases (6), ischemic stroke (16), pregnancy complications such as preterm birth (22), diabetes (11), and pneumonia (3). In traditional medicine, medicinal herbs are used in balancing oral microbiota (13).

In the present study, we investigated the inhibition properties of 16 plant ethanol extracts against standard strains of cariogenic bacteria: Streptococcus mutans (S. mutans), Streptococcus mitis (S. mitis), Streptococcus sanguinis (S. sanguinis), Lactobacillus acidophilus ( $L$. acidophilus) and bacteria involved in paradontopathy: Actinomyces odontolyticus (A. odontolyticus), Eikenella corrodens (E. corrodens), Fusobacterium nucleatum ( $F$. nucleatum). Ethanol extracts were made from medicinal plants often used in Serbian ethnomedicine.

\section{Material and methods}

Collection of plant material. The following medicinal plants were collected in northern Serbia: the free-growing plants Aesculus hippocastanum, Artemisia absinthium, Capsella bursa-pastoris, Hypericum perforatum and Thymus vulgaris, and the cultivated plants Achillea millefolium, Calendula officinalis, Malva mauritanica, Origanum majorana, Plantago lanceolata, Sinapis alba, Tilia cordata, Teucrium montanum, Acorus calamus, as well as Salvia officinalis and Rosmarinus officinalis which are both freegrowing and cultivated medicinal plants. 
Bacterial strains. Investigated strains were: $A$. odontolyticus ATCC 17929, S. mitis ATCC 6249, S. sanguinis ATCC 10556, E. corrodens ATCC 23834, F. nucleatum ATCC 25586, L. acidophilus ATCC 4356 and S. mutans ATCC 25175 (Microbiologics).

Preparation of ethanolic extracts. Dry plants (150 g) were milled into fine powder with an electric blender. Extraction was done in a percolator, using $500 \mathrm{ml}$ of $(70 \%)$ ethanol, with low-pressure evaporation following extraction. The content of the extract was left for at least $16 \mathrm{~h}$. The amount of the extract was six times the volume of the starting drug ( $1: 6$ extract). The extract was stored and finally passed through a $0.22 \mu \mathrm{m}$ filter (Millipore, Billerica, MA). After the dry substance had been obtained in an evaporator, the extracts were kept at $4^{\circ} \mathrm{C}$ until use (22).

Antimicrobial activity. The ethanol extracts were individually tested against specific bacterium. Bacteria were cultured overnight at $37^{\circ} \mathrm{C}$ in Mueller Hinton broth (HiMedia), $\mathrm{pH}=7.4$.

Determination of the minimum inhibitory concentration (MIC). The method applied for the evaluation of the antimicrobial activity was minimum inhibitory concentration (MIC) by the method of agar dilution (CLSI, 2010.). Serial dilutions of plant extracts were prepared in plates, and the assay plates were estimated to contain $300,150,75$ and $37.5 \mu \mathrm{g} / \mathrm{ml}$ of active extracts. Inocula were applied on surfaces of blood agar (Liofilchem) giving approximately $10^{6} \mu \mathrm{g} / \mathrm{ml}$ of bacteria. All plates were incubated for about 48 to $72 \mathrm{~h}$ under anaerobic conditions at $37^{\circ} \mathrm{C}$. MIC was taken as the lowest concentration of extract that produced no visible bacterial growth as compared to the control growth. The extracts were tested in triplicates.

Tab. 1. MICs $(\mu \mathrm{g} / \mathrm{ml})$ of 16 herbal extracts for some members of oral microbiota

\begin{tabular}{|c|c|c|c|c|c|c|c|}
\hline Plants Bacteria & 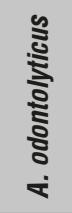 & $\begin{array}{l}\text { 鸟 } \\
\text { cं }\end{array}$ & 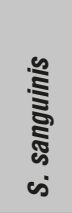 & 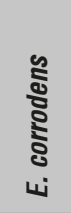 & 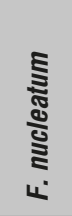 & 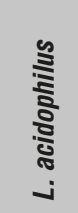 & 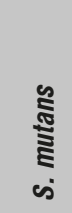 \\
\hline Sinapis alba & 37.5 & $>300$ & 75 & 75 & 75 & 150 & 300 \\
\hline Thymus vulgaris & 37.5 & $>300$ & 37.5 & 37.5 & 37.5 & 75 & 37.5 \\
\hline Rosmarinus officinalis & 37.5 & $>300$ & 37.5 & 37.5 & 37.5 & $>\mathbf{3 0 0}$ & 37.5 \\
\hline Hypericum perforatum & 37.5 & $>300$ & 37.5 & 37.5 & 37.5 & $>\mathbf{3 0 0}$ & 300 \\
\hline Teucrium montanum & 37.5 & $>300$ & 37.5 & 37.5 & 75 & 300 & 75 \\
\hline Artemisia absinthium & 37.5 & $>300$ & 37.5 & 75 & 75 & 150 & 300 \\
\hline Plantago lanceolata & 37.5 & $>300$ & 75 & 37.5 & 75 & 75 & 75 \\
\hline Salvia officinalis & 37.5 & $>300$ & 37.5 & 37.5 & 37.5 & $>300$ & 37.5 \\
\hline Calendula officinalis & 37.5 & $>300$ & 37.5 & 37.5 & 37.5 & 37.5 & 150 \\
\hline Acorus calamus & 300 & 300 & 300 & 300 & 300 & 75 & 300 \\
\hline Malva mauritanica & 75 & $>300$ & 300 & 75 & 150 & 75 & 300 \\
\hline Tilia cordata & 150 & $>300$ & 150 & 150 & 300 & 150 & $>300$ \\
\hline Aesculus hippocastanum & 75 & $>300$ & 75 & 37.5 & 300 & 75 & 300 \\
\hline Capsella bursa-pastoris & 37.5 & $>300$ & 300 & 75 & 300 & 300 & 300 \\
\hline Origanum majorana & 37.5 & 150 & 37.5 & 37.5 & 150 & 75 & 150 \\
\hline Achillea millefolium & 150 & 300 & 150 & 150 & 150 & 300 & 300 \\
\hline
\end{tabular}

\section{Results and discussion}

Extracts of Rosmarinus officinalis, Salvia officinalis, Thymus vulgaris, Calendula officinalis and Hypericum perforatum were efficient against most investigated bacteria $(5 / 5),(5 / 5),(5 / 6),(5 / 6)$ and $(4 / 5)$, respectively, with MICs of $37.5 \mu \mathrm{g} / \mathrm{ml}$. Acorus calamus extract had the lowest efficiency of MICs $=300 \mu \mathrm{g} / \mathrm{ml}$ for most oral bacteria (6/7) except for L. acidophilus (MIC $=75 \mu \mathrm{g}$ / $\mathrm{ml})$. Aesculus hippocastanum extract had high MICs for F. nucleatum and $S$. mutans $(300 \mu \mathrm{g} / \mathrm{ml})$. Moderate efficiency is shown against $A$. odontolyticus, $S$. sanguinis and L. acidophilus $(75 \mu \mathrm{g} / \mathrm{ml})$, but the exeption was E. corrodens with MIC of $37.5 \mu \mathrm{g} / \mathrm{ml}$. Among oral streptococci, $S$. mutans was the most resistant strain to examined plant extracts, exept to T. vulgaris, $R$. officinalis and $S$. officinalis extracts (Tab. 1). F. nucleatum expresed the highest sensitivity to $T$. vulgaris, $R$. officinalis, H. perforatum, S. officinalis and C. officinalis extracts $(37.5 \mu \mathrm{g} / \mathrm{ml})$ and less sensitivity to $A$. calamus, Tilia cordata, A. hippocastanum and Capsella bursapastoris $(300 \mu \mathrm{g} / \mathrm{ml})$. A. odontolyticus were the most sensitive bacteria with MICs of $37.5 \mu \mathrm{g} / \mathrm{ml}$ to extracts of: Sinapis alba, T. vulgaris, R. officinalis, H. perforatum, Teucrium montanum, Artemisia absinthium, Plantago lanceolata, S. officinalis, C. officinalis, C. bursa-pastoris and Origanum majorana, but less sensitive to Malva mauritanica and A. hippocastanum $(75 \mu \mathrm{g} / \mathrm{ml})$. These bacteria expressed the least sensitivity to T. cordata, Achillea millefolium $(150 \mu \mathrm{g} / \mathrm{ml})$ and A. calamus extracts $(300 \mu \mathrm{g} / \mathrm{ml})$.

The human oral microbiota is based on a substantial number of microorganisms with complex interactions, which at the same time represent normal microbiota of the human cavity and reservoir for bacteria that participate in the etiology of local and systemic disease.

The ethanol extracts of Rosmarinus officinalis, Salvia officinalis, Thymus vulgaris, Calendula officinalis and Hypericum perforatum were the most efficient in this research, with MICs of $37.5 \mu \mathrm{g} / \mathrm{ml}$ for majority of investigated bacteria. On the other hand, Acorus calamus extract had the highest MICs $=300 \mu \mathrm{g} / \mathrm{ml}$ for most oral pathogens. Of all tested strains, $S$. mutans were the most resistant bacteria.

Shruthi and Geetha (29) showed that $T$. vulgaris extracts had very good antibacterial activity against $S$. sanguinis and $S$. mutans. Results in previous studies in which methanolic extracts and aqueous extracts of T. vulgaris showed no effect either on S. mutans or S. sanguinis (4) could 
be explained by the use of different solvents. Clinical investigation on effects of $T$. vulgaris ethanolic extract on pulpitis, indicated for pulpothomy, supported experimental findings on the antimicrobial effect of this plant on oral microbiota (2).

In contrast to our results, Lauk et al. (18) documented a lower inhibitory activity (MIC $\geq 2048 \mathrm{mg} / \mathrm{L}$ ) of C. officinalis methanol extracts against paradontopathic bacteria $F$. nucleatum, E. corrodens and A. odontolyticus.

The present study showed an inhibitory concentration of $S$. officinalis at $37.5 \mu \mathrm{g} / \mathrm{ml}$ for $S$. mutans. Moreover, significant reduction in the $S$. mutans colony count has been recorded in vivo evaluations as well as in the agar diffusion method $(7,32,17)$.

Antimicrobial activity of $R$. officinalis L. propylene glycol extract showed a significant reduction in colony forming units per mililiter $(\mathrm{CFU} / \mathrm{ml})$ in all biofilms at MIC of $200 \mathrm{mg} / \mathrm{ml}(23,30)$. Also, some studies revealed that dentifrice containing alcoholic $R$. officinalis extract had antimicrobial activity similar to commercially available herbal dentifrice against some streptococci (32).

In our research, the effect of Achillea millefolium extract showed moderate activity against $A$. odontolyticus, S. sanguinis, E. corrodens and F. nucleatum, with MICs of $150 \mu \mathrm{g} / \mathrm{ml}$, while its activity against $S$. mitis, $L$. acidophilus and $S$. mutans was low with MICs of $300 \mu \mathrm{g} / \mathrm{ml}$. These results, although there are some differences in MICs, are in accordance with previous studies revealing the activity of $A$. millefolium extract as a possible supplement in preparations against oral bacteria. On the other hand, S. mitis was the most susceptible of the tested organisms to the herbal mixture extract of Juniperus communis, Urtica dioca and A. millefolium, with an MIC value of $1 \mathrm{mg} / \mathrm{ml}$ (35).

At the MICs of $37.5 \mu \mathrm{g} / \mathrm{ml}$ and of $75 \mu \mathrm{g} / \mathrm{ml}$, in the present study Artemisia absinthium ethanol extract expressed very good antimicrobial activity against A. odontolyticus and $S$. sanguinis and good activity against $E$. corrodens and $F$. nucleatum, respectively. However, we observed weak activity against $L$. acidophilus (MIC $=150 \mu \mathrm{g} / \mathrm{ml}$ ) and especially weak activity against $S$. mutans $(\mathrm{MIC}=300 \mu \mathrm{g} / \mathrm{ml}$ ) which is similar to results of Vieira et al. (34) (MIC $=250$ $\mu \mathrm{g} / \mathrm{ml})$, although there was differences in the used preparations.

Soleimanpour et al. (31) found no resistance in investigated strains ( $S$. mutans and $S$. sanguinis) to the antibacterial activity of Capsella bursa-pastoris ethanol extracts and its combination with Glycyrrhiza glabra. Since our results are the opposite, showing the highest values of MICs $(300 \mu \mathrm{g} / \mathrm{ml})$ for $S$. mutans and $S$. sanguinis as well as for F. nucleatum and L. acidophilus, it could be suggested that mixed extract was more effective against all bacteria, indicating its synergistic effect.
The assessment of Aesculus hippocastanum antibacterial activity found aqueous and ethanolic extracts being effective against tested oral bacteria ( $S$. mutans, $S$. sanguinis and L. acidophilus), while the ethanol extract was more effective against $S$. mutans and $S$. sanguinis (27). In our research the MIC of $A$. hippocastanum ethanol extract against $S$. mutans was $300 \mu \mathrm{g} / \mathrm{ml}$ and for $S$. sanguinis and L. acidophilus $75 \mu \mathrm{g} / \mathrm{ml}$, which is considerably different in comparison to previous studies.

A. calamus $\mathrm{L}$. is described as an incredible herb because of its medicinal characteristics (14). However, there is little evidence of its activity against oral bacteria. While the $A$. calamus ethanol extract was active against all the investigated bacterial strains, aqueous extract was completely inactive against some investigated Gram-negative bacteria and active at a high concentration only against some Gram-positive bacteria (20). We registered L. acidophilus ( $\mathrm{MIC}=75 \mu \mathrm{g} / \mathrm{ml}$ ) to be the most sensitive bacteria to A. calamus ethanol extract, while MICs for all other investigated bacteria were $300 \mu \mathrm{g} / \mathrm{ml}$.

Most of the studies revealed good antibacterial activity of $H$. perforatum ethanol extract against different strains of pathogenic bacteria $(5,21)$, as well as against Bifidobacterium animalis and L. plantarum (25). In our study, ethanol extract of $H$. perforatum possessed very good antibacterial activity against all investigated bacteria (MIC $=37.5 \mu \mathrm{g} / \mathrm{ml}$ ) exept for S. mutans $(300 \mu \mathrm{g} / \mathrm{ml})$.

Of the tested bacteria in the present investigation, the most resistant strains ( $\mathrm{MIC}=150 \mu \mathrm{g} / \mathrm{ml}$ ) to Origanum majorana ethanol extract were $S$. mitis, $S$. mutans and F. nucleatum. Previous studies of Hajlaoui et al. (12) confirmed higher MICs of O. majorana essential oil for Pseudomonas aeruginosa, Salmonella typhimurium and Vibrio parahaemolyiticus. In contrast, Chaudhry et al. (8) have shown a great antibacterial potential of O. majorana essential oil and aqueous infusion against Citrobacter spp. and Klebsiella pneumoniae, Klebsiella ozaenae, Enterobacter aerogenes, respectively.

Because of the significant decrease in streptococci in the oral cavity, some authors concluded that Plantago lanceolata extract could be a natural anticariogenic agent through its antimicrobial effect and useful in the proliferation control of cariogenic flora (10). In our research, the strongest activities of $P$. lanceolata ethanol extracts were observed against $A$. odontolyticus and E. corrodens $(\mathrm{MIC}=37.5 \mu \mathrm{g} / \mathrm{ml}$ ), while $S$. mutans and S. sanguinis had MICs of $75 \mu \mathrm{g} / \mathrm{ml}$ as did L. acidophilus and F. nucleatum. On the other hand, ethanol extract of $P$. major did not show any activity against primary plaque colonizers or periodontal pathogens (28).

In our investigation, ethanol extracts of Teucrium montanum and of Sinapis alba showed good antimicrobial activities against the investigated oral microbiota, with the exception of $L$. acidophilus and $S$. mutans $(\mathrm{MIC}=300 \mu \mathrm{g} / \mathrm{ml})$, respectively. 
As determined by the disc diffusion method, the crude ethanol extracts as well as its fractions of Malva parviflora have shown good antibacterial effect against Staphylococcus aureus and Escherichia coli (1). The activity of $M$. mauritanica ethanol extract in our study against oral bacteria was good, except for $S$. sanguinis and $S$. mutans with MICs of $300 \mu \mathrm{g} / \mathrm{ml}$.

The strong antimicrobial activity of Tilia cordata was found against Listeria ivanovii, but the highest activity of methanolic extract was measured against Pseudomonas aeruginosa with disc diffusion method (33). Our investigation of T. cordatata ethanol extract efficiency showed a moderate activity against A. odontolyticus, S. sanguinis, E. corrodens and L. acidophilus with MICs of $150 \mu \mathrm{g} / \mathrm{ml}$ and a weak effect on F. nucleatum with MIC of $300 \mu \mathrm{g} / \mathrm{ml}$.

Ethanol extracts of Rosmarinus officinalis, Salvia officinalis, Thymus vulgaris, Calendula officinalis and Hypericum perforatum were shown to be the most effective against investigated bacteria, while Acorus calamus extract displayed a minimum of efficacy. However, the most resistant bacteria among oral streptococci and investigated anarobes were $S$. mutans strains. The results from this study indicate that plant extracts could be used in oral health as a therapeutic and prophylactic approach or in balancing oral microbiota.

\section{References}

1. Abdel-Ghani A. E., Hanaa H. M., El-Shazl A. M.: Phytochemical and biological study of Malva parviflora L. grown in Egypt. Zagazig J. Pharm. Sci. 2013, 22, 17-25.

2.Alolofi H., El-Sayed M., Taha T.: Clinical and radiographical evaluation of propolis and Thymus vulgaris extracts compared with formocresol pulpotomyin human primary molars. BDJOPEN 2016, 2, 16005.

3. Awano S., Ansai T., Takata Y., Soh I., Akifusa S., Hamasaki T., Yoshida A., Sonoki K., Fujisawa K., Takehara T.: Oral health and mortality risk from pneumonia in the elderly. J. Dent. Res. 2008, 87, 334-339.

4. Babpour E., Angaji S., Angaj S. M.: Antimicrobial effects of four medicinal plants on dental plaque. J. Med. Plants Res. 2009, 3, 132-137.

5. Barbagallo C., Chisari G.: Antimicrobial activity of three Hypericum species. Fitoterapia 1987, 58, 175-177.

6. Beck J. D., Offenbacher S.: Systemic effects of periodontitis: epidemiology of periodontal disease and cardiovascular disease. J. Periodontol. 2005, 76 , 2089-2100.

7. Beheshti-Rouy M., Azarsina M., Rezaie-Soufi L., Alikhani M. Y., Roshanaie G., Komaki S.: The antibacterial effect of sage extract (Salvia officinalis) mouthwash against Streptococcus mutans in dental plaque: a randomized clinical trial. Iran. J. Microbiol. 2015, 7, 173-177.

8. Chaudhry N. M. A., Saeed S., Tariq P.: Antibacterial effects of oregano (Origanum vulgare) against Gram negative bacilli. Pak. J. Bot. 2007, 39, 609-613.

9.Dewhirst F. E., Chen T., Izard J., Paster B. J., Tanner A. C., Yu W. H., Lakshmanan A., Wade W. G.: The human oral microbiome. J. Bacteriol. 2010, 192, 5002-5017.

10. Ferrazzano G. F., Cantile T., Roberto L., Ingenito A., Catania M. $R$ Roscetto E., Palumbo G., Zarrelli A., Pollio A.: Determination of the in vitro and in vivo antimicrobial activity on salivary Streptococci and Lactobacilli and chemical characterisation of the phenolic content of a Plantago lanceolata infusion. Biomed. Res. Int. 2015, 2015, 286817.

11. Genco R. J., Grossi S. G., Ho A., Nishimura F., Murayama Y.: A proposed model linking inflammation to obesity, diabetes, and periodontal infections. J. Periodontol. 2005, 76, 2075-2084.

12. Hajlaoui H., Mighri H., Gharsallah M. A. N., Kadri A.: Chemical composition and in vitro evaluation of antioxidant, antimicrobial, cytotoxicity and antiacetylcholinesterase properties of Tunisian Origanum majorana L. essential oil. Microbial. Pathogenesis 2016, 95, 86-94.
13. Haque M. M., Alsareii S. A.: A review of the therapeutic effects of using miswak (Salvadora Persica) on oral health. Saudi Med. J. 2015, 36, 530-543.

14. Imam H., Riaz Z., Azhar M., Sofi G., Hussain A.: Sweet flag (Acorus calamus Linn.): an incredible medicinal herb. Int. J. Green Pharm. 2013, 7, 288-296.

15. Iwami Y.: Rate-limiting steps of the glycolytic pathway in the oral bacteria Streptococcus mutans and Streptococcus sanguis and the influence of acidic $\mathrm{pH}$ on the glucose metabolism. Arch. Oral Biol. 1980, 25, 163-169.

16. Joshipura K. J., Hung H. C., Rimm E. B., Willett W. C., Ascherio A.: Periodontal disease, tooth loss, and incidence of ischemic stroke. Stroke 2003, 34, 47-52.

17. Kemanshah H., Hashemi K. S. S., Arami S., Mirsalehian A., Kamalinegad M., Karimi M., Jabalameli F.: Comparison of antibacterial effect of hydroalcoholic extract of four plants against cariogenic microorganisms by two in vitro methods. JBUMS 2011, 13, 21-29.

18. Lauk L., Lo Bue A. M., Milazzo I., Rapisarda A., Blandino G.: Antibacterial activity of medicinal plant extracts against periodontopathic bacteria. Phytother. Res. 2003, 17, 599-604.

19. Lederberg J., Mccray A. T.: 'Ome sweet' omics - a genealogical treasury of words. Scientist 2001, 15, 8-10.

20. Manikandan S., Devi R. S., Srikumar R., Thangaraj R., Ayyappan R., Jegadeesh $R$., Lakshmanan $H$.: In vitro antibacterial activity of aqueous and ethanolic extracts of Acorus calamus. Int. J. Appl. Biol. Pharm. Technol. 2010, 1, 1072-1075

21. Molochko V. A., Lastochkina T. M., Krylov I. A., Brangulis K. A.: The antistaphylococcal properties of plant extracts in relation to their prospective use as therapeutic and prophylactic formulations for the skin. Vestn. Dermatol. Vener. 1990, 8, 54-56.

22. Offenbacher S., Jared H. L., O'Reilly P. G., Wells S. R., Salvi G. E., Lawrence H. P., Socransky S. S., Beck J. D.: Potential pathogenic mechanisms of periodontitis associated pregnancy complications. Ann. Periodontol. 1998, 3, 233-250.

23. Oliveira J. R. de, Jesus D. de, Figueira L. W., Oliveira F. E. de, Soares C. P., Camargo S. E. A., Jorge A. O. C., Oliveira L. D. de: Biological activities of Rosmarinus officinalis L. (rosemary) extract as analyzed in microorganisms and cells. Exp. Biol. Med. (Maywood) 2017, 242, 625-634.

24. Paster B. J., Boches S. K., Galvin J. L., Ericson R. E., Lau C. N., Levanos V. A., Sahasrabudhe A., Dewhirst F. E.: Bacterial diversity in human subgingival plaque. J. Bacteriol. 2001, 183, 3770-3783.

25. Reichling J., Weseler A., Saller R.: A current review of the antimicrobial activity of Hypericum perforatum L. Pharmacopsychiatry 2001, 34, 116-118.

26. Reynolds-Campbell G., Nicholson A., Thoms-Rodriguez C. A.: Oral bacterial infections: Diagnosis and management. Dent. Clin. North. Am. 2017, 61, 305-318.

27. Roy A., Geetha R. V., Lakshmi T.: In vitro evaluation of antibacterial activity of aqueous and ethanolic extracts of Aesculus hippocastanum on oral microbes. Asian J. Pharm. Clin. Res. 2011, 4, 90-92.

28. Sharma H., Yunus G. Y., Mohapatra A. K., Kulshrestha R., Agrawal R., Kalra M.: Antimicrobial efficacy of three medicinal plants Glycyrrhiza glabra, Ficus religiosa, and Plantago major on inhibiting primary plaque colonizers and periodontal pathogens: An in vitro study. Indian J. Dent. Res. 2016, 27, 200-204.

29. Shruthi D., Geetha R. V.: Effect of herbal extracts in prevention of dental caries - an in vitro study. Int. J. Drug Dev. Res. 2018, 10, 20-21.

30. Silva B. N. de, Nakassugi L. P., Faggion P. O. J., Kohiyama C. Y., Mossini S. A., Grespan R., Nerilo S. B., Mallmann C. A., Alves A. F. B., Machinski M. Jr.: Antifungal activity and inhibition of fumonisin production by Rosmarinus officinalis L. essential oil in Fusarium verticillioides (Sacc.) Nirenberg. Food Chem. 2015, 166, 330-336.

31. Soleimanpour S., Sedighinia F. S., Afshar A. S., Zarif R., Asili J., Ghazvini K. Synergistic antibacterial activity of Capsella bursa-pastoris and Glycyrrhiza glabra against oral pathogens. Jundishapur J. Microbiol. 2013, 6, e7262.

32. Valones M. A., Higino J. S., Souza P. R., Crovella S., Caldas A. F. Jr, Carvalho A. A.: Dentifrice containing extract of Rosmarinus officinalis Linn.: an antimicrobial evaluation. Braz. Dent. J. 2016, 27, 497-501.

33. Vatlák A., Kolesárová A., Vukovič N., Rovná K., Petrová J., Vimmerová V. Hleba L., Mellen M., Kačániová M.: Antimicrobial activity of medicinal plants against different strains of bacteria. J. Microbiol. Biotech. Food Sci. 2014, 3, 174-176

34. Vieira T. M., Dias H. J., Medeiros T. C. T., Grundmann C. O., Groppo M., Heleno V. C. G., Martins C. H. G., Cunha W. R., Crotti A. E. M., Silva E. O.: Chemical composition and antimicrobial activity of the essential oil of Artemisia absinthium Asteraceae leaves. JEOP 2017, 20, 123-131.

35. Weijden G. A. van der, Timmer C. J., Timmerman M. F., Reijerse E., Mantel M. S., Velden U. van der: The effect of herbal extracts in an experimental mouthrinse on established plaque and gingivitis. J. Clin. Periodontol. 1998 $25,399-403$

Corresponding author: Professor Zoran Tambur DVM, PhD, Zarka Zrenjanina 179, 26000 Pancevo, Serbia; e-mail: tambur.zoran@gmail.com 